\title{
Effects of phenology, site, and rumen fill on tall larkspur consumption by cattle
}

JAMES A. PFiSTER, GARY D. MANNERS, MICHAEL H. RALPHS, ZHAO XIAO HONG, AND MARK A. LANE

\section{Abstract}

Tall larkspur (Delphinium barbeyi) is a major cause of liveatock death on mountain ranges. The influence of plant phenology, grazing site, and rumen fill on tall larkspur consumption was evaluated during July and August, 1987. Livestock consumption of larkspur was determined using bite counts during 4 phenological stages: bud, early flower, flower, and pod. Further, we examined larkspur ingestion in a shaded tree site and in an open sun site at 0 , 50, and $100 \%$ rumen fill levels using ruminally cannulated steers. Steers on the 0,50 , and $100 \%$ fill levels consumed 9,15 , and $17 \%$ larkspur, respectively $(P=0.15)$. There was a site effect $(P=0.06)$ with steers eating 17 and $11 \%$ larkspur in the shade and sun sites, respectively. Over the summer, larkspur comprised $6 \%$ of cattle diets. No larkspur was consumed during the bud stage. Larkspur consumption peaked at $10 \%$ of cattle diets during the pod stage. Leaves of tall larkspur contained $>3 \%$ total alkaloids (dry weight) in early July, but declined greatly with maturation. Larkspur was very nutritious, with crude protein levels 12 to $20 \%$, and fiber levels $<20 \%$ during most of the summer. Cattle diets, as determined with esophageally fistulated animals, were also high in crude protein and low in fiber during the summer. We propose a toxic window hypothesis relating larkspur palatability and toxicity. This hypothesis predicts that most cattle losses will occur during the flowering stage. We found that tall larkspur was unpalatable to cattle from the bud stage until the flowering racemes had elongated, and then consumption generally increased with plant maturation. Even though palatability and consumption increase during the graxing season, cattle can graze tall larkspur with a much lower risk of toxicosis when toxicity is low later in the graxing season.

Key Words: poisonous plants, cattle diets, Delphinium berbeyi, alkaloids, grazing behavior

Tall larkspur (Delphinium spp.) has been characterized as the most serious poisonous plant problem on western U.S. mountain rangelands (Ralphs et al. 1988). The toxin(s) in larkspur are diterpenoid alkaloids (Pelletier and Keith 1970). Total alkaloid content may be related to plant toxicity (Olsen 1977a); however, individual alkaloids, or combinations thereof probably provide more reliable predictions of toxicity (Olsen 1983).

There is little information on when and how much tall larkspur is consumed by grazing livestock. Early poisonous plant researchers commented that tall larkspur plants were unpalatable to cattle after flowering, but they gave no data to substantiate their remarks (see Glover 1906, Marsh et al. 1916, and Marsh et al. 1929). Recent research has not supported these comments. Pfister et al. (1988) reported that cattle grazing mountain ranges ate large, but not fatal, quantities of $D$. barbeyi during summer. Larkspur plants of all phenological stages were present on the pasture during the

\footnotetext{
Pfister and Ralphs are range scientists, USDA-ARS Poisonous Plant Research Lab., Logan, Utah 84321; Manners is research chemist, Western Regional Research Center, Albany, Calif. 94710; Hong is research associate, Grassland Institute, Urumqi, Xinjiang, China; and Lane was graduate research assistant, Dept. of Range Science, Utah State University, Logan.

We thank Larry Mickelsen for valuable assistance with the field work, Dr. John Olsen for surgery, Dr. Dave Clark for laboratory analyses and Dr. Don Sisson for statistical advice. Dr. Jim Bowns, Dr. George Ruyle and Dr. Walter Majak reviewed an earlier draft, and we thank them for their helpful comments.

Manuscript accepted 25 July 1988.
}

study, but cattle consumed tall larkspur only from flowering plants (Pfister et al. 1988).

Numerous reports from ranchers and researchers (e.g. Marsh et al. 1929) indicate that cattle losses are more severe immediately after rain or snow showers. Several plant and animal factors may interact to increase losses under these circumstances. Marsh et al. (1929) believed these increased losses were probably because cattle congregated under groves of trees where larkspur was abundant. Hunger may be aroused (Toates 1980) after cattle spend several hours under tree shelter during storms. Larkspur alkaloids are $\mathrm{N}$-based secondary metabolites, and the fertilizing effect of animals bedding in groves of trees may influence both the palatability and toxicity of adjacent tall larkspur plants. Gershenzon (1984) noted that supplementary $\mathbf{N}$ promoted alkaloid production in numerous species. Further, differences in shading can alter the chemistry of forage plants compared to others grown in full sunlight (Majak et al. 1977, Wilson 1982).

We wished to test 2 hypotheses: first, based on previous work (Pfister et al. 1988), we felt that cattle did not consume $D$. barbeyi before the flowering stage. Therefore, we investigated tall larkspur consumption during 4 phenological stages: bud, early flower, full flower, and pod. Second, we hypothesized that cattle selection for tall larkspur would differ in exposed areas receiving full light compared to selection for partially shaded plants within and adjacent to a grove of trees. Cattle used the tree area as a source of shade while loafing and as a bedding ground many nights. Further, we wished to determine if rumen fill influenced tall larkspur consumption at these 2 sites.

\section{Materials and Methods}

The study site was located at the head of Six Mile Canyon, near Manti, Utah, at 3,200 m elevation. Precipitation at the study site occurs mainly as winter snowfall and as summer thundershowers; precipitation totaled $12.7 \mathrm{~cm}$ during July and August, 1987. A description of the study area and the dominant vegetation was given by Pfister et al. (1988). Briefly, tall larkspur patches dominate areas where snow accumulates during winter. Dense currant (Ribes spp.) mottes and open grass-forb associations dominate the remainder of the non-wooded landscape.

\section{Phenological Stage}

The effect of phenological stage of tall larkspur on consumption by grazing cattle was determined using 4 experimental periods. Period 1 (bud stage) was from 2 July to 11 July. Virtually all larkspur plants within the pasture were in the bud stage, and elongation of flowering racemes had not begun for most plants. Larkspur plants were classified as flowering after elongation of the racemes. After elongation, flowers typically require at least 2 to 3 days to open fully. Period 2 (early flower) was from 20 July to 30 July. Approximately $50 \%$ of larkspur plants had elongated flowering racemes at the beginning of this period, and by the end of the period about $80-90 \%$ of the larkspur plants had elongated racemes. Period 3 (full flower) was from 5 August to 14 August. Most larkspur plants had flowered early in this period, and about $10 \%$ were beginning to set seed. By the end of this trial, about $50 \%$ 
of larkspur plants were in the pod stage. Period 4 (pod stage) was from 19 August to 30 August. Over $95 \%$ of larkspur plants were in the early to late pod stage at the beginning of period 4 . When period 4 ended, some larkspur pods were shattering, and many plants were yellow and senescent.

Different contiguous pastures with abundant larkspur populations were used for each period. Pastures varied in size from about 2 to 3.5 ha, and were enclosed with electric fence. Five yearling Hereford heifers ( $318 \mathrm{~kg}$ body weight) that had grazed on the area the previous summer as calves were used to determine larkspur consumption. A bite count technique was used as described by Pfister et al. (1988) to determine relative amounts of tall larkspur eaten by cattle.

Larkspur plant parts were collected for analysis of total alkaloid concentration (TAC) at the beginning and end of each period. Samples were frozen in the field using dry ice and ethanol, and later freeze dried and ground through a $1-\mathrm{mm}$ screen with a Wiley mill. TAC was determined using a modification of the procedure of Pelletier et al. (1981) as reported by Pfister et al. (1988).

Standing crop was determined at the beginning and end of each period as detailed by Pfister et al. (1988), by clipping 30 to $40, .25 \mathrm{~m}$ $X 1 \mathrm{~m}$ plots. Tall larkspur biomass was estimated using a doublesampling procedure as described by Pfister et al. (1988). Tall larkspur biomass was determined once during each period on each pasture.

Tall larkspur utilization was estimated at the end of periods 2 to 4 using 20 to $30,1 \mathrm{~m}^{2}$ plots along transect lines as detailed in Pfister et al. (1988). No utilization estimates were made at the end of period 1 because no larkspur had been eaten.

The proportion of time the heifers spent grazing in each of the dominant vegetation areas (larkspur, grass-forb, currant) was calculated based on behavioral observations for each period. During focal-animal sampling for bite counts the vegetation area grazed and time of entry and departure was noted for each focal animal. Preference for a particular vegetation area $\left(P_{i}\right)$ during active grazing times was calculated as $P_{i}=\log$ (percentage occupation of vegetation area $_{i} /$ percentage of study area covered by vegetation area ${ }_{i}$ ) (Putman et al. 1987). No preference is indicated by $P_{i}=0$; positive or negative numbers mean selection or avoidance of areas, respectively (Putman et al. 1987). As used here, this index does not consider area preferences for activities other than grazing.

Diet quality was determined at the beginning and end of periods 1,2 , and 4 using 3 esophageally fistulated Hereford heifers that had also grazed this area the previous summer. Diet samples were collected in pasture areas representative of the tall larkspur vegetation area, currant area, and the grass-forb area. The fistulated heifers were tethered with a $10 \mathrm{~m}$ rope to a steel post, and allowed to graze for $\mathbf{3 0}$ to $\mathbf{4 0} \mathrm{min}$. Heifers were rotated through the 3 sampling areas during the morning feeding period on a random basis. Diet samples were frozen in the field using dry ice and ethanol, and later freeze dried and ground through a $1-\mathrm{mm}$ screen. Diet and clipped larkspur samples were analyzed for crude protein (CP) using a macroKjeldahl procedure (Harris 1967), and for neutral detergent fiber (NDF) or acid detergent fiber (ADF) using the procedures of Goering and Van Soest (1975). The ADF procedure was substituted for NDF for diet samples because of unresolvable filtering difficulties.

Measurements of temperature and relative humidity were made using a continuous recording hygrothermograph. Barometric pressure was measured using a fortin type mercurial barometer. Precipitation was measured in a wide-mouth rain gauge to accomodate snow or sleet. Larkspur consumption was correlated with temperature, barometric pressure (corrected for gravity and ambient temperature), previous 12- and 24-hour precipitation, relative humidity, and temperature-humidity index (THI). THI was calculated as $\left(T_{d b}\right)-\left[(0.55-0.55 R H)\left(T_{d b}-58\right)\right]$, where $T_{d b}$ is dry bulb temperature, and RH is relative humidity (Ingraham et al. 1979). THI has been found useful as an index of stress in cattle (Ingraham et al. 1979).

\section{Site and Rumen Fill}

The second experiment compared the selectivity of cattle for partially shaded larkspur growing within and adjacent (within 10 m) to a grove of trees (shade site) with larkspur growing in an open, unshaded area over $100 \mathrm{~m}$ from cattle bedding grounds (sun site). The influence of rumen fill was also evaluated using 3 ruminally cannulated Holstein steers ( $330 \mathrm{~kg}$ body weight) that had grazed an adjacent area from $20 \mathrm{July}$ as an adaptation period. The Holstein steers and the heifers selected virtually identical diets $(P>0.1)$ after the first 5 days of this adaptation period (Pfister, unpublished data). This experiment was done during the flower stage ( 7 to 12 August) and the pod stage (24 to 30 August).

During each trial rumen fill treatments were imposed by removing rumen contents via rumen cannulae. The $0 \%$ fill treatment resulted in complete removal of all rumen contents into a large metal container. For the $50 \%$ fill treatment, all rumen contents were removed, and $50 \%$ by volume was immediately replaced. Residual contents from the $50 \%$ treatment were used to completely fill the rumen of the $100 \%$ treatment animal. Treatments were imposed each day at 1000,1030, and 1100, 2 hours before the animals were observed, to allow any physiological feedback mechanisms to operate. Animals were rotated through the treatments in a systematic fashion during each 6-day period. At the designated time, each animal was led to one site and observed for $15 \mathrm{~min}$. Steers were secured with a $10 \mathrm{~m}$ tether to a steel post, and allowed to graze while bite counts were taken. Standing crop measurements were not taken at the sites, but each site had adequate larkspur and other forage for selective grazing. All animals were very tractable and thoroughly trained in the procedure before trial 1 began. To minimize the possibility of carryover effects (i.e. destruction of microbial populations from cooling and aeration of rumen con-

Table 1. Mean forage availability (kg/ha) on the experimental pastures during summer, 1987.

\begin{tabular}{|c|c|c|c|c|c|c|c|c|}
\hline & \multicolumn{8}{|c|}{ Period } \\
\hline & \multicolumn{2}{|c|}{1} & \multicolumn{2}{|c|}{2} & \multicolumn{2}{|c|}{31} & \multicolumn{2}{|c|}{4} \\
\hline & Jul 2 & Jul 11 & Jul 20 & Jul 30 & Aug 5 & Aug 14 & Aug 19 & Aug 30 \\
\hline $\begin{array}{l}\text { Graminoids } \\
\text { Taraxacum officinale } \\
\text { Artemisia ludoviciana } \\
\text { Lupinus spp. } \\
\text { Mertensia leonardi } \\
\text { Other forbs } \\
\text { Forb subtotal } \\
\text { D. barbeyi }\end{array}$ & $\begin{array}{c}110 \mathrm{a}^{2} \\
56 \mathrm{a} \\
137 \mathrm{a} \\
38 \mathrm{a} \\
216 \mathrm{a} \\
237 \mathrm{a} \\
684\end{array}$ & $\begin{array}{r}116 \mathrm{a} \\
42 \mathrm{a} \\
176 \mathrm{a} \\
59 \mathrm{a} \\
23 \mathrm{~b} \\
274 \mathrm{a} \\
594\end{array}$ & $\begin{array}{r}183 a \\
101 a \\
245 a \\
58 a \\
30 a \\
368 a \\
775\end{array}$ & $\begin{array}{r}248 \mathrm{a} \\
64 \mathrm{a} \\
220 \mathrm{a} \\
20 \mathrm{a} \\
0 \mathrm{a} \\
354 \mathrm{a} \\
658\end{array}$ & 172 & 148 & $\begin{array}{r}236 a \\
126 a \\
108 a \\
57 a \\
125 a \\
400 a \\
789\end{array}$ & $\begin{array}{r}131 \mathrm{a} \\
72 \mathrm{a} \\
96 \mathrm{a} \\
25 \mathrm{a} \\
0 \mathrm{~b} \\
224 \mathrm{~b} \\
417\end{array}$ \\
\hline
\end{tabular}

'Data adapted from Lane (1987); no species separation was done except for $D$. barbeyi.

${ }_{2}^{2}$ Means in the same row for the same period followed by the same letter are not different using a $95 \%$ confidence interval. 
tents), 6 to 8 liters of rumen contents from a fourth ruminally cannulated steer were given to the $0 \%$ fill animal when its rumen contents were restored each day at 1330 . No inappetence following the treatments was noted. Between the grazing periods the steers were kept corralled, and all animals were fed sufficient amounts of alfalfa hay in separate feedings at 1400 and 2000 to allow ad libitum consumption during the evening. Usually only small amounts of residual feed were present at 0630 .

\section{Statistical Analysis}

All data were analyzed using the Statistical Analysis System (SAS 1985). Bite count data were transformed using an aresinesquare root transformation (Steel and Torrie 1980). To compare percent of bites of major diet components, animals were considered as blocks, and periods as treatments, with repeated measurements over days within periods. Chi-square analysis was used to compare cattle distribution in the currant, grass-forb and larkspur vegetation areas, compared to the proportion of each area in the study pastures. If cattle grazed at random, the number of minutes of observation time in an area (observed values) would be similar to the total minutes of observation time multiplied by the proportion of the pasture occupied by that vegetation (expected values). Changes in nutritive value of cattle diets and forage availability were evaluated using $95 \%$ confidence intervals. To evaluate the influence of site and rumen fill, the 3 ruminally cannulated Holstein steers were used in a pooled Latin square, with sites, animals and rumen fill levels as main effects; days were nested within site, and the trial was repeated during the flower and pod stages of growth.

\section{Results \\ Forage and Larkspur Availability}

Forage was not limiting during any of the periods (Table 1). Period 1 began relatively early in the growing season, yet ample forage was present for animals to graze selectively. Rapid plant growth nearly kept pace with consumption during periods 1 and 2 . The standing crop of both forbs and grasses was diminished during period 3. During period 4, cattle reduced the total standing crop by about $50 \%$ (Table 1 ).

There was a moderate amount of larkspur available for grazing during period $1(165 \mathrm{~kg} / \mathrm{ha}$ of dry matter). Larkspur was very suculent, and over $900 \mathrm{~kg} / \mathrm{ha}$ was present on a wet basis. During period 1 larkspur comprised about $17 \%$ of the available forage $(\mathrm{dm}$ basis). Relatively more larkspur was present during periods 2 to 4 (Table 1) due to increasing dry matter content and pasture differences.

Table 2. Total alkaloid concentration ( $\%$ dry wt.) of tall larkspur durins 1987.

\begin{tabular}{lccccc}
\hline \hline & \multicolumn{5}{c}{ Plant Part } \\
\cline { 2 - 6 } Date & Stem & Leaf & Bud & Flower & Pod \\
\hline $7 / 2 / 87$ & 1.46 & 3.11 & 1.48 & & \\
$7 / 10 / 871$ & 1.03 & 3.09 & 1.24 & & \\
$7 / 10 / 872$ & 0.59 & 1.46 & 1.26 & & \\
$7 / 21 / 87$ & 0.41 & 1.65 & & 0.77 & \\
$7 / 25 / 87$ & 0.41 & 1.89 & & 0.85 & \\
$7 / 31 / 87$ & 0.39 & 1.84 & & 0.87 & \\
$8 / 10 / 87$ & 0.49 & 0.98 & & 0.78 & 1.15 \\
$8 / 12 / 87$ (shade) & & & & 0.92 & 1.08 \\
$8 / 12 / 87$ (sun)4 & & & & 0.96 & 1.31 \\
$8 / 19 / 87$ & 0.39 & 0.63 & & 0.86 & 0.96 \\
$9 / 1 / 87$ & 0.14 & 0.23 & & & 1.02 \\
$9 / 1 / 87$ (shade) & & & & & 1.14 \\
$9 / 1 / 87$ (sun) & & & & & 1.23 \\
\hline
\end{tabular}

ISamples from tall larkspur plants before elongation of racemes.

2Samples from tall larkspur plants after elongation of racemes.

3Samples from tall larkspur plants grown in partial shade.

¿Samples from tall larkspur plants grow in full sun.

\section{Larkspur Utilization}

No larkspur was consumed during period 1 . During periods 2 to 4,54 to $60 \%$ of the flower and pod apexes showed evidence of grazing. Utilization of leaves (at least one grazed leaf) varied from $12 \%$ of stalks during period 2 to $70 \%$ at the end of period 4 .

\section{Total Alkaloid Content of Larkspur}

Leaves of tall larkspur were highest in TAC during the early growing season (Table 2), but leaf TAC declined rapidly with plant maturation. Flowers and pods maintained different but relatively constant TAC during the early and latter part of the summer, respectively. Larkspur plant parts grown under partial shade in the tree site were consistently lower in TAC than were parts collected from plants grown in full sunlight.

\section{Phenology and Larkspur Consumption}

Averaged over the summer, larkspur comprised $6.1 \%$ of cattle diets. The amount of larkspur consumed was different among periods $(P<0.05)$. Cattle ate no larkspur during period 1 , the bud stage (Table 3). During the early flower stage (period 2), the heifers consumed only a trace amount of larkspur buds, always from plants with some flowering racemes. Cattle selected nearly all flowers during this early flowering stage. Larkspur consumption decreased during the flower stage (period 3) to about 6\% (Table 3).

Table 3. Dietary components (\% of bltes) and bite rate (bitea $/ \mathrm{min}$ ) by cattle graxing mountain ranges in central Utah during 1987.

\begin{tabular}{|c|c|c|c|c|c|c|}
\hline \multirow[b]{2}{*}{ Item } & \multicolumn{4}{|c|}{ Period } & \multirow[b]{2}{*}{ Mean } & \multirow[b]{2}{*}{$P$ value } \\
\hline & 1 & 2 & 3 & 4 & & \\
\hline $\begin{array}{c}\text { Larkspur bud } \\
\text { flower } \\
\text { leaf } \\
\text { stem } \\
\text { pod } \\
\text { Total Larkspur }\end{array}$ & $\begin{array}{l}0 \\
0 a^{1} \\
0 a \\
0 \\
0 a \\
0 a\end{array}$ & $\begin{array}{l}0.2 \\
6.5 \mathrm{~b} \\
1.2 \mathrm{a} \\
0.02 \\
0.01 \mathrm{a} \\
8.0 \mathrm{~b}\end{array}$ & $\begin{array}{c}0 \\
2.9 \mathrm{~b} \\
1.1 \mathrm{a} \\
0.02 \\
2.2 \mathrm{~b} \\
6.2 \mathrm{~b}\end{array}$ & $\begin{array}{l}0 \\
0.04 \mathrm{a} \\
8.0 \mathrm{~b} \\
0.1 \\
2.2 \mathrm{~b} \\
10.2 \mathrm{~b}\end{array}$ & $\begin{array}{l}0.05 \\
2.4 \\
2.7 \\
0.03 \\
1.1 \\
6.1\end{array}$ & $\begin{array}{l}>0.05 \\
<0.01 \\
<0.01 \\
>0.1 \\
<0.01 \\
<0.01\end{array}$ \\
\hline $\begin{array}{l}\text { Graminoids } \\
\text { Taraxacum }\end{array}$ & 25.8 & 25.4 & 20.4 & 22.3 & 23.5 & $>0.05$ \\
\hline $\begin{array}{l}\text { officinale } \\
\text { Mertensia }\end{array}$ & $19.9 \mathrm{a}$ & $11.0 \mathrm{c}$ & $17.8 \mathrm{ab}$ & 13.4b & 15.3 & $<0.01$ \\
\hline $\begin{array}{l}\text { leonardi } \\
\text { Other forbs } \\
\text { Total forbs }\end{array}$ & $\begin{array}{l}9.3 a \\
44.9 \\
74.1\end{array}$ & $\begin{array}{c}0.3 b \\
55.3 \\
66.5\end{array}$ & $\begin{array}{l}2.1 \mathrm{c} \\
53.0 \\
72.8\end{array}$ & $\begin{array}{l}2.3 \mathrm{c} \\
50.7 \\
66.3\end{array}$ & $\begin{array}{r}3.4 \\
51.1 \\
69.7\end{array}$ & $\begin{array}{l}<0.01 \\
>0.1 \\
>0.1\end{array}$ \\
\hline Shrubs & 0.1 & 0.1 & 0.6 & 1.2 & 0.5 & $>0.1$ \\
\hline Bite rate & $21.4 \mathrm{a}$ & $29.0 \mathrm{~b}$ & $31.3 \mathrm{~b}$ & $29.7 \mathrm{~b}$ & 27.9 & $<0.01$ \\
\hline
\end{tabular}

'Means in the same row followed by the same letter are not different $(P>0.05)$.

Cattle selected nearly equivalent amounts of flowers and pods as pods were beginning to form. Consumption of larkspur peaked at $10 \%$ during period 4 , the pod stage. There was a day effect $(P<0.05)$ and a day by period interaction $(P<0.05)$ for consumption of total larkspur, and larkspur flowers and pods.

There was no difference $(P>0.05)$ between periods for grass, shrub, or forb consumption (excluding larkspur). Cattle diets were about $70 \%$ forbs and $23 \%$ grass over the summer. Taraxacum officinale was highly preferred by cattle in each period, as was Mertensia leonardi when available. Shrubs were a minor dietary component. Correlation coefficients $(r)$ between larkspur consumption and environmental variables were low; the highest correlation ( $r=-0.31$ ) was with THI. In a multiple regression analysis, no subset of variables had a $r^{2}$ value above 0.16 .

\section{Cattle Distribution and Diets}

Cattle did not graze randomly in the pastures. The animals preferentially grazed the currant and larkspur areas, and avoided the grass-forb area (Table 4). Cattle concentrated $(P<0.001)$ in the larkspur areas during period $2\left(P_{\mathrm{i}}=.37\right)$ and $3\left(P_{\mathrm{i}}=.52\right)$. There was a marked influence of vegetation area on cattle diets (Table 4). Cattle 
Table 4. Cattle distribution (\% of graxing tme) compared to vegetation area, and percent of bites in each vegetation area.

\begin{tabular}{|c|c|c|c|c|c|c|c|}
\hline \multirow[b]{2}{*}{$\begin{array}{l}\text { Time } \\
\text { Vegetation area }\end{array}$} & \multirow[b]{2}{*}{$\begin{array}{l}\% \text { of } \\
\text { area }\end{array}$} & \multirow[b]{2}{*}{$\begin{array}{c}\% \text { of grazing } \\
\text { time }\end{array}$} & \multirow[b]{2}{*}{$P_{\mathrm{i}}{ }^{1}$} & \multirow[b]{2}{*}{$\begin{array}{l}\text { Sig. } \\
\text { level }\end{array}$} & \multicolumn{3}{|c|}{$\%$ of bites 3} \\
\hline & & & & & Larkspur & 0. Forbs & Grass \\
\hline $\begin{array}{l}\text { Period } 1 \\
\text { currant } \\
\text { grass-forb } \\
\text { larkspur }\end{array}$ & $\begin{array}{l}10 \\
79 \\
11\end{array}$ & $\begin{array}{r}20 \\
74 \\
6\end{array}$ & $\begin{array}{r}.30 \\
-.03 \\
-.26\end{array}$ & $\begin{array}{l}0.001 \\
\text { NS } \\
0.001\end{array}$ & $\begin{array}{l}0 \\
0 \\
0\end{array}$ & $\begin{array}{l}81.1 \\
70.8 \\
81.3\end{array}$ & $\begin{array}{l}18.2 \\
29.2 \\
18.7\end{array}$ \\
\hline $\begin{array}{l}\text { Period } 2 \\
\text { currant } \\
\text { grass-forb } \\
\text { larkspur }\end{array}$ & $\begin{array}{r}27 \\
65 \\
8\end{array}$ & $\begin{array}{l}16 \\
66 \\
18\end{array}$ & $\begin{array}{l}-.23 \\
0.0 \\
.37\end{array}$ & $\begin{array}{c}0.001 \\
\text { NS } \\
0.01\end{array}$ & $\begin{array}{r}4.6 \\
0.2 \\
46.9\end{array}$ & $\begin{array}{l}87.6 \\
68.1 \\
43.3\end{array}$ & $\begin{array}{r}7.7 \\
31.5 \\
9.8\end{array}$ \\
\hline $\begin{array}{l}\text { Period } 3 \\
\text { currant } \\
\text { grass-forb } \\
\text { larkspur }\end{array}$ & $\begin{array}{l}16 \\
74 \\
10\end{array}$ & $\begin{array}{l}33 \\
33 \\
34\end{array}$ & $\begin{array}{r}.32 \\
-.35 \\
.52\end{array}$ & $\begin{array}{l}0.001 \\
0.001 \\
0.001\end{array}$ & $\begin{array}{r}1.1 \\
0.4 \\
19.2\end{array}$ & $\begin{array}{l}73.8 \\
74.0 \\
68.7\end{array}$ & $\begin{array}{l}23.7 \\
25.6 \\
11.8\end{array}$ \\
\hline $\begin{array}{l}\text { Period } 4 \\
\text { currant } \\
\text { grass-forb } \\
\text { larkspur }\end{array}$ & $\begin{array}{l}26 \\
44 \\
30\end{array}$ & $\begin{array}{l}35 \\
44 \\
21\end{array}$ & $\begin{array}{l}.13 \\
0.0 \\
-.17\end{array}$ & $\begin{array}{c}0.001 \\
\text { NS } \\
0.001\end{array}$ & $\begin{array}{r}16.0 \\
3.0 \\
32.4\end{array}$ & $\begin{array}{l}68.0 \\
61.7 \\
55.9\end{array}$ & $\begin{array}{l}15.6 \\
32.3 \\
11.2\end{array}$ \\
\hline $\begin{array}{l}\text { Overall } \\
\text { currant } \\
\text { grass-forb } \\
\text { larkspur }\end{array}$ & $\begin{array}{l}20 \\
65 \\
15\end{array}$ & $\begin{array}{l}25 \\
57 \\
18\end{array}$ & $\begin{array}{r}.11 \\
-.06 \\
.09\end{array}$ & $\begin{array}{l}0.001 \\
0.001 \\
0.001\end{array}$ & $\begin{array}{r}6.3 \\
0.8 \\
24.9\end{array}$ & $\begin{array}{l}76.4 \\
68.7 \\
62.4\end{array}$ & $\begin{array}{l}16.7 \\
29.8 \\
12.5\end{array}$ \\
\hline
\end{tabular}

$1 P_{1}$ is preference index indicating animal preference for vegetation areas. Values less than or greater than zero indicate avoidance or selection of an area, respectively.

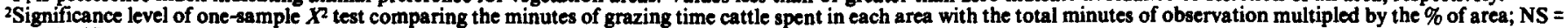
non-significant.

3May not total to $100 \%$ because shrubs are not included.

diets were $25 \%$ larkspur on average when grazing in the larkspur areas, compared to 6 and $1 \%$ for the currant and grass-forb areas, respectively. Cattle consumed $47 \%$ larkspur during period 2 when grazing in larkspur areas.

\section{Nutritive Value of Larkspur and Cattle Diets}

Tall larkspur leaves, buds, flowers and pods contained high levels (12 to 30\%) of CP and low levels (12 to 20\%) of NDF (Fig. 1). Cattle diets were very nutritious early in summer, but generally declined in CP and increased in ADF levels with forage maturation (Fig. 2). Few differences $(P<0.05)$ in dietary $\mathrm{CP}$ or ADF content were noted among vegetation areas on the same date.

\section{Site and Rumen Fill Trial}

Larkspur consumption tended to vary with rumen fill $(P=0.15)$. The steers on the 0,50 and $100 \%$ levels of rumen fill consumed 9.3 , 14.6 , and $17.3 \%$ larkspur, respectively over both periods. There was a site effect $(P=0.06)$, with steers taking 16.9 and $10.6 \%$ larkspur bites in the shade and sun areas, respectively (Table 5). Periods were not different $(P>0.1)$. There was no site by rumen fill interaction $(P=0.1)$.

Biting rate decreased $(P<0.05)$ with increasing levels of rumen fill (Table 5). Overall, the 0,50 , and $100 \%$ fill treatments averaged $29.6,25.4$, and 21.2 bites/min. Biting rate also was significantly $(P<0.05)$ higher in the sun area $(29.2$ bites $/ \mathrm{min})$ compared to the shade area (21.6). No period effect $(P>0.1)$ was noted for biting rate.

\section{Discussion}

This study confirms previous observations (Pfister et al. 1988) that $D$. barbeyi is generally unpalatable to cattle before flowering. These findings are in contrast to early reports indicating that cattle selected more tall larkspur before flowering than after (Glover 1906; Marsh et al. 1929), but these early reports did not state the Delphinium species. In our studies, $D$. barbeyi was not consumed by cattle until the flowering racemes began elongation. Consumption of flowering parts and leaves began then and increased with plant maturation. Cronin and Nielsen (1979) noted that cattle

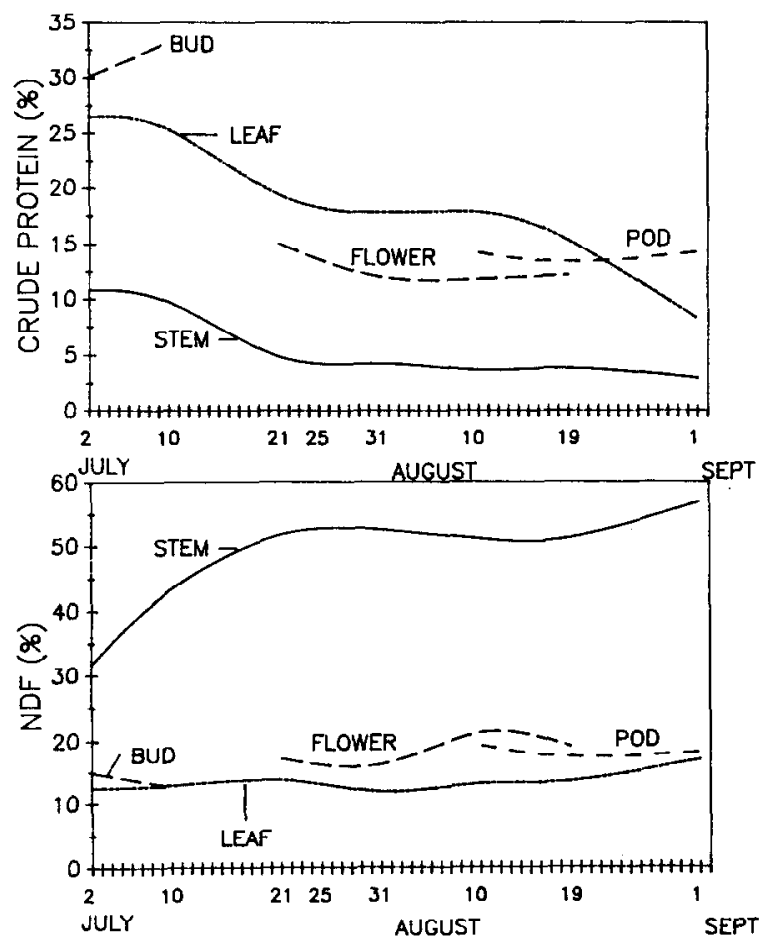

Fis. 1. Crude protein and neutral detergent fiber (NDF) levels in tall larkspur during summer, 1987.

selected young leaves and stem tips of $D$. barbeyi early in the season, but did not indicate if the racemes had elongated. Knowles (1974) reported cattle deaths from consumption of $D$. glaucescens and $D$. occidentale early in the grazing season, but no phenological stages were specified.

Between 50 and $60 \%$ of the flower and pod apexes were grazed 
Table 5. Percent of larkspur bites and biting rate (bites/min) at two sites for steers with different levels of rumen fill.

\begin{tabular}{|c|c|c|c|c|c|c|}
\hline \multirow{2}{*}{$\begin{array}{l}\text { Level of } \\
\text { rumen fill } \\
(\%)\end{array}$} & \multicolumn{3}{|c|}{ \% Larkspur bites } & \multicolumn{3}{|c|}{ Biting rate } \\
\hline & $\begin{array}{l}\text { shade } \\
\text { site }\end{array}$ & $\begin{array}{l}\text { sun } \\
\text { site }\end{array}$ & SE $\mathbf{l}$ & $\begin{array}{l}\text { shade } \\
\text { site }\end{array}$ & $\begin{array}{l}\text { sun } \\
\text { site }\end{array}$ & SE \\
\hline $\begin{array}{r}0 \\
50 \\
100 \\
\text { SE }\end{array}$ & \begin{tabular}{r|}
12.7 \\
14.2 \\
23.7 \\
3.2
\end{tabular} & $\begin{array}{r}5.9 \\
15.1 \\
10.8 \\
2.7\end{array}$ & $\begin{array}{l}2.6 \\
3.4 \\
4.5\end{array}$ & $\begin{array}{c}25.0 \\
21.7 \\
18.0 \\
1.2\end{array}$ & \begin{tabular}{r|}
34.1 \\
29.0 \\
24.0 \\
1.8
\end{tabular} & $\begin{array}{l}2.1 \\
1.8 \\
1.6\end{array}$ \\
\hline
\end{tabular}

ISE = Standard error of the mean.

during each period after the bud stage. During this and the previous summer (Pfister et al. 1988), pastures were stocked at a comparable level ( 27 to 33 cattle days/ ha), and larkspur utilization estimates were similar. Logan (1973) found that cattle utilization of
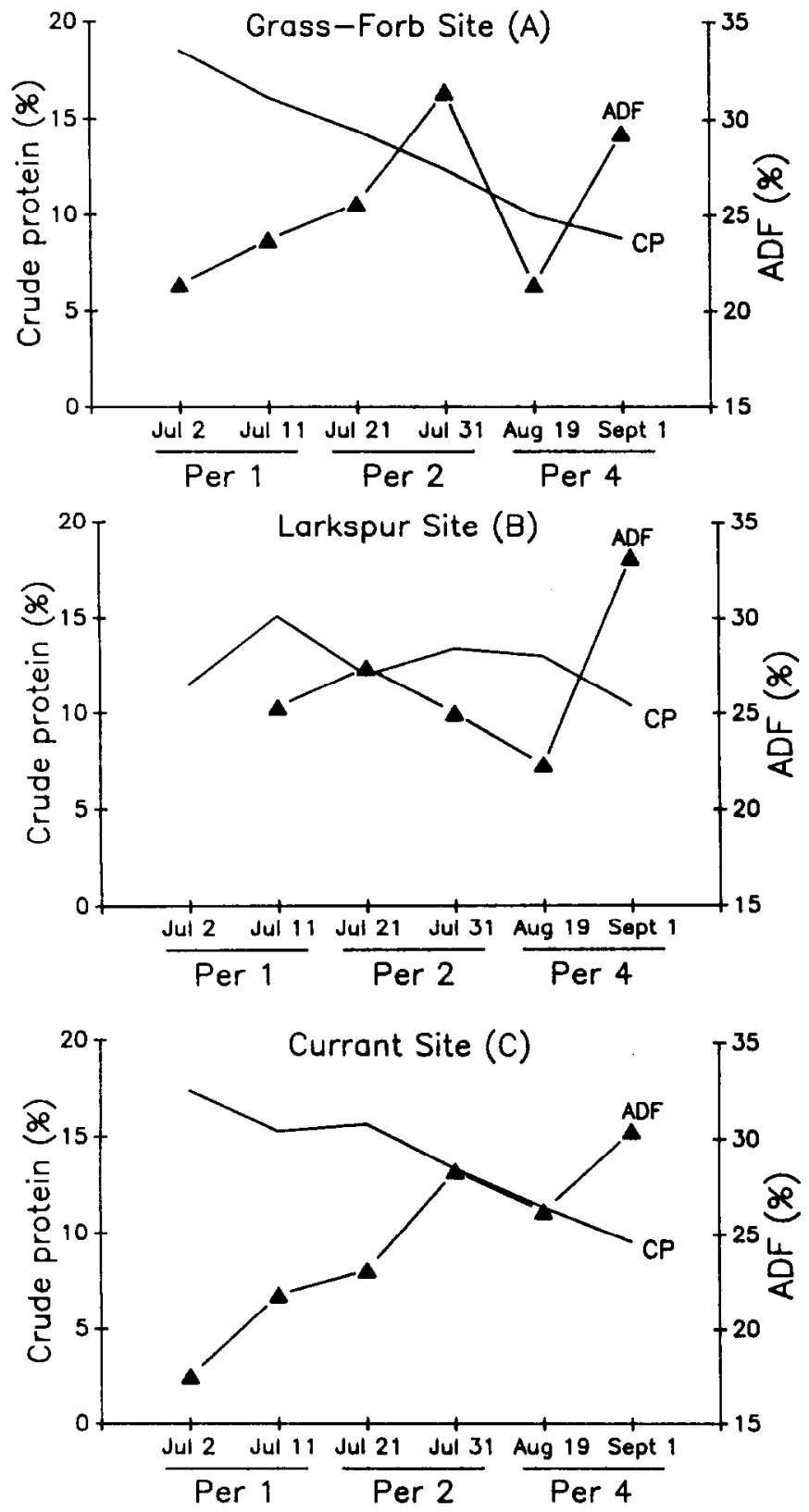

Fig. 2. Crude protein (CP) and acid detergent fiber $(A D F)$ levels in diets selected by esophageally fistulated cattle in (a) grass-forb sites, (b) larkspur sites, and (c) currant sites during periods 1,2 , and 4 corresponding to the bud, early flower, and pod stages of tall larkspur in 1987.

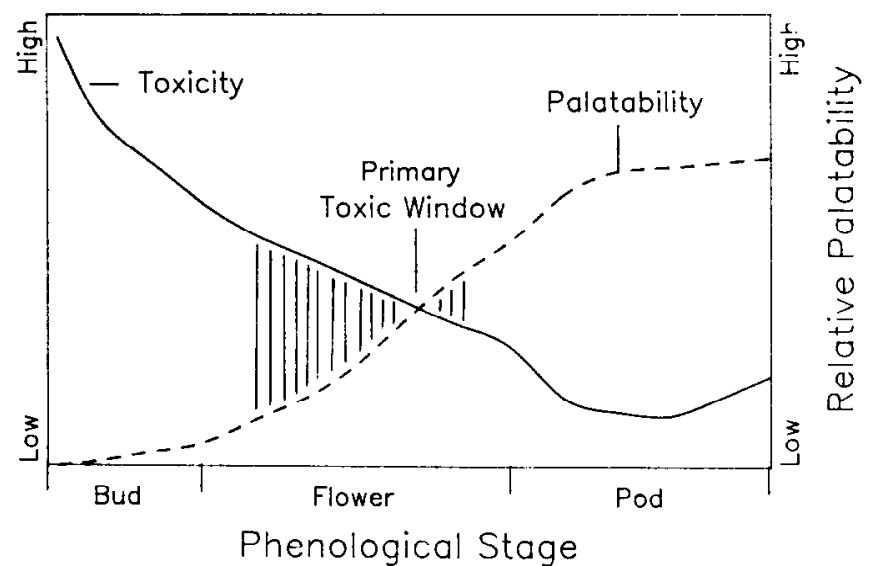

Fig. 3. Hypothetical relationship between palatability and toxicity of $\mathrm{D}$. barbeyi indicating a primary toxic window when most cattle deaths may be predicted.

D. occidentale in Idaho was highest in late summer at maturity. In the Manti area, stocking rate does not appear to be a contributing factor to losses from tall larkspur as pastures are normally grazed at a moderate level.

Alkaloid levels of tall larkspur during 1987 were similar to 1986 results (Pfister et al. 1988). Williams and Cronin (1966) reported comparable TAC in leaves of $D$. barbeyi. However, TAC of $D$. occidentale plants were substantially higher than $D$. barbeyi for both apexes and leaves (Williams and Cronin 1966), even though $D$. occidentale is 10 times less toxic to rats than $D$. barbeyi (Olsen 1977b). Data on TAC without knowledge of toxicity of individual alkaloids may be misleading (Olsen 1983). D. occidentale differs from $D$. barbeyi in presence or absence of several unidentified individual alkaloids (Manners, unpublished data). For example, the toxic alkaloid in the tall larkspur $D$. brownii is methyllycaconitine, a potent neuromuscular blocking agent (Nation et al. 1982), but the plant contains other alkaloids (Aiyar et al. 1979).

Cattle tended to consume more larkspur with increasing levels of rumen fill. This suggests that even though larkspur is palatable, hungry cattle will generally select other forbs and grasses over larkpur. This may be due to reduced selectivity by hungry animals.

Steers took more larkspur bites in the shade site compared to the sun site. TAC of flowers and pods were slightly higher in the sun plants than in the shaded plants, but these small differences could be due to chance. The influences of proximity to cattle bedding grounds (i.e. $\mathrm{N}$ fertilization effect) and partial shading on TAC are unknown. Plant levels of CP and NDF were similar between the 2 sites (data not given). Louda et al. (1987) reported that insect herbivory of sun-grown $D$. nelsoni was greater than for shaded plants, but no information on TAC was given.

The nutritive value of tall larkspur is high, and cattle can consume large amounts of $D$. barbeyi with no apparent ill effects. During this and a previous summer, cattle ate large quantities of tall larkspur at times, with no death losses among the experimental animals. In the areas surrounding the experimental pastures, cattle losses attributed by ranchers to tall larkspur were about 5 to $10 \%$. No fatal episodes of gluttonous consumption (Cronin and Nielsen 1979) were observed, so we still have little information on factors responsible for triggering this feeding behavior. On 2 occasions (late July and mid-August), cattle in this study displayed unusual feeding behavior for 15 to 20 min periods by rapidly consuming larkspur, then running from larkspur plant to plant, and occasionally eating plants to ground level. Each episode followed a cold rainshower, and the cattle were playful and active. Increased excitability is symptomatic of larkspur toxicosis (Nation et al. 1982), and increased movement may potentiate toxic effects (J.D. Olsen, personal communication). We suspect that weather-induced chemical changes in the plants may be responsible for these alterations in 
feeding behavior. Plant samples taken after the late July incident were slightly higher in TAC compared to levels several days earlier (Pfister, unpublished data). Keeler and Laycock (1988) noted that rapid diurnal fluctuations in levels of toxins have been reported for other alkaloid-containing plants.

These grazing studies of tall larkspur indicate that there is a primary toxic window, during which $D$. barbeyi is both palatable and toxic, due to levels of one or several individual alkaloids. This hypothesis predicts that most cases of fatal consumption will occur just after flowering, and this period may last for several weeks (Fig. 3). Observations of fatal gluttonous consumption (Cronin and Nielsen 1979) were not seen during our grazing studies, and are problematic for the toxic window hypothesis. During such episodes, cattle ingest fatal quantities of entire plants (Cronin and Nielsen 1979) when larkspur presumably contains high total alkaloid levels (Williams and Cronin 1966). The plant fraction that deters herbivory of immature larkspur is thought to be alkaloids (Ralphs and Olsen 1987), because of a bitter taste (Bate-Smith 1972). If one or several highly toxic alkaloids are not the deterrent fraction, then reductions in levels of other, less toxic alkaloids (or some other deterrent fraction such as resins or phenols) may trigger gluttonous consumption by cattle. For example, although tannin levels have been strongly implicated in chemical defense of birch (Betula resinifera) against herbivory by snowshoe hares (Bryant and Kuropat 1980), current evidence indicates that other compounds are in fact rendering the plant unpalatable (Reichardt et al. 1984). Bioassays to determine acceptability of chemical extracts of larkspur are currently underway in our laboratory, and may help to answer some questions about larkspur/ livestock interactions.

\section{Literature Cited}

Alyar, V.N., M.H. Benn, T. Hanna, J. Jacyno, S.H. Roth, and J.L. Wilkens. 1979. The principal toxin of Delphinium brownii Rydb., and its mode of action. Experientia 35:1367-1368.

Bate-Smith, E.C. 1972. Attractions and repellents in higher animals. p. 45-56. In: Phytochemical ecology, (J.B. Harborne ed.). Academic Press, New York.

Bryant, J.P., and P.J. Kuropat. 1980. Selection of winter forage by subartic browsing vertebrates: the role of plant chemistry. Annu. Rev. Ecol. Syst. 11:261-285.

Cronin, E.H., and D.B. Nielsen. 1981. Larkspurs and livestock on the rangelands of western North America. Down to Earth 37:11-16.

Gershenzon, J. 1984. Changes in the levels of plant secondary metabolites under water and nutrient stress. p. 273-320. In: Recent advances in phytochemistry, Vol. 18, (B.N. Timmermann, C. Steelink, and F.A. Loewus eds.), Plenum Press, New York.

Glover, G.H. 1996. Larkspur and other poisonous plants. Colo. Agr. Exp. Sta. Bull. 113.

Goering, H.K., and P.J. Van Soest. 1970. Forage fiber analyses. USDA Agr. Hand. 379.

Harris, L.E. 1967. Nutrition research techniques for domestic and wild animals. Vol. 1. Logan, Utah.

Ingraham, R.H., R.W. Stanley, and W.C. Wagner. 1979. Seasonal effects of tropical climate on shaded and nonshaded cows as measured by rectal temperature, adrenal cortex hormones, and milk production. Amer. J. Vet. Res. 40:1792-1797.

Keeler, R.F., and W.A. Laycock. 1988. Use of plant information in management decisions. p. 347-362. In: The ecology and economic impact of poisonous plants on livestock production, (L.F. James, M.H. Ralphs, and D.B. Nielsen eds.) Westview Press, Denver, Colo.
Knowles, K. 1974. An evaluation of larkspur poisoning in cattle and the trampling damage that occurs during grazing on a summer range in eastern Idaho. M.S. thesis, Univ. Idaho, Moscow.

Lane, M.A. 1987. Conditioned taste aversion: potential for reducing cattle losses to larkspur. M.S. Thesis, Utah State Univ., Logan.

Logan, J.R. 1973. Evaluation of a specifically formulated supplement for the prevention of larkspur poisoning. M.S. Thesis, Utah State Univ., Logan.

Louda, S.M., P.M. Dixon and N.J. Huntly. 1987. Herbivory in sun versus shade at a natural meadow-woodland ecotone in the Rocky Mountains. Vegetatio 72:141-149.

Majak, W., P.D. Parkinson, R.J. Williams, N.E. Looney, and A.L. Van Ryswyk. 1977. The effect of light and moisture on Columbia milkvetch toxicity in lodgepole pine forests. J. Range Manage. 30:423-427.

Marsh C.D., A.B. Clawson, and H. Marsh. 1929. Larkspur or poison weed. USDA Bull. 988.

Marah, C.D., A.B. Clawson, and H. Marsh. 1916. Larkspur poisoning of livestock. USDA Bull. 365.

Nation, P.N., M.H. Benn, S.H. Roth, and J.L. Wilkens. 1982. Clinical signs and studies of the site of action of purified larkspur alkaloid, methyllycaconitine, administered parenterally to calves. Can. Vet. J. 23:264-266.

Olsen, J.D. 1977a. Rat bioassy for estimating toxicity of plant material from larkspur (Delphinium sp.). Amer. J. Vet. Res. 38:277-279.

Olsen, J.D. 1977b. Toxicity of extract from 3 larkspur species (Delphinium barbeyi, $D$. glaucescens, $D$. occidentale) measured by rat bioassay. J. Range Manage. 30:237-238.

Olsen, J.D. 1983. Relationship of relative total alkaloid concentration and toxicity of duncecap larkspur during growth. J. Range Manage. 36:550-552.

Pelletier, S.W., and L.H. Keith. 1970. Diterpene alkaloids from Aconitum, Delphinium, and Garrya species. p. 1-206. In: The Alkaloids, Vol. XII, (R.H.F. Manske ed.). Academic Press, New York.

Pelletier, S.W., O.D. Dailey, Jr., N.V. Mody, and J.D. Olsen. 1981. Isolation and structure elucidation of alkaloids of Delphinium glaucescens Rybd. J. Org. Chem. 46:3284-3293.

Prister, James A., Michael H. Ralphs, and Gary D. Manners. 1988. Cattle grazing tall larkspur on Utah mountain ranges. J. Range Manage. 41:118-122.

Putman, R.J., R.M. Pratt, J.R. Ekins, and P.J. Edwards. 1987. Food and feeding behaviour of cattle and ponies in the New Forest, Hampshire. J. Appl. Ecol. 24:369-374.

Ralphs, M.H., and J.D. Olsen. 1987. Alkaloids and palatability of poisonous plants. p. 78-83. In: Proc.-Symposium on plant-herbivore interactions. (F.D. Provenza, E.D. McArthur, and J.T. Flinders ed.). USDA For. Ser. Int. Gen. Tech. Rep. INT-222.

Ralphs, M.H., J.D. Olsen, J.A. Pfister, and G.D. Manners. 1988. Plantanimal interactions in larkspur poisoning in cattle. J. Anim. Sci. 66:2334-2342.

Reichardt, P.B., J.P. Bryant, T.P. Clawen, and G.D. Wieland. 1984. Defense of winter-dormant Alaska paper birch against snowshoe hares. Oecologia 65:58-59.

SAS Institute, Inc. 1985. SAS/STAT guide for personal computers, Version 6 Edition. Cary, North Carolina.

Steel, R.G.D., and J.H. Torrie. 1980. Principles and procedures of statistics. 2nd Edition. McGraw-Hill Book Co., New York.

Toates, F.W. 1980. Animal behavior-a systems approach. John Wiley and Sons, New York.

Williams, M.C., and E.H. Cronin. 1966. Five poisonous range weeds-when and why they are dangerous. J. Range Manage. 19:274-279.

Wilson, J.R. 1982. Environmental and nutritional factors affecting herbage quality. p. 111-131. In: Nutritional limitations to animal production from pastures, (J.B. Hacker ed.). Commonwealth Agricultural Bureaux, Farnham Royal, United Kingdom. 